\title{
The Effect of Customer Relationship Marketing on Customer Satisfaction: A Comparative Study on the Selected Resorts in the Southern Ethiopia
}

\author{
Lidetu Alemu Anjulo (Assistant Professor) \\ Lecturer, Department of Management: Wolita Sodo University. P.o.box:138
}

\begin{abstract}
Relationship marketing provides avenues for service providers to listen and address the concerns and needs of customers in a bid to promote customer value and satisfaction. The general objective of this study was to assess the effect of relationship marketing on Customers' satisfaction on the two hotels namely Haile and Lewi resort in the Southern Ethiopia. The study implemented cross sectional survey design. To collect primary data, structured questionnaire and semi-structured interview were used. Respondents were selected by using convenience sampling method in order to fill questionnaire. And also purposive sampling technique was used to select managers from each resort. 384 structured questionnaires were distributed to the customers of both Haile and Lewi resorts, only 365 (95\%) complete responses were returned from the customers. The finding result indicates that relationship marketing dimensions (independent variables) such as trust, commitment, communication, empathy and responsiveness are positively correlated with customer satisfaction for both resorts. According to regression model summary result for Haile resort, $\mathrm{R}$ Square $=.711$ means customers satisfaction is the result of 71.1 percent change in all independent variables. And also for Lewi resort, $\mathrm{R}$ Square $=.680$ means that customer satisfaction is predicted by 68.0 percent change in all independent variables. Therefore, the findings of this thesis suggests that resorts should incorporate the relationship marketing dimensions to their marketing strategy so as to increase overall customer satisfaction and in turn to generate benefits from the relationship with customers that is currently critical to success in this dynamic business environment with increasing preferences and competition in the market.
\end{abstract}

Keywords: Customer Relationship, Marketing dimensions, Customer satisfaction, customer value DOI: $10.7176 / \mathrm{JMCR} / 53-02$

\subsection{Background of the Study}

Relationship marketing began during 20th century to dominate the marketing field. At that time relationship marketing became a major issue in marketing and managing business (Egan, 2001). Relationship marketing has been developed over the years as stimulating area of marketing that emphasize on creating and maintaining longterm relationships with customers and other parties. In the competitive market, organizations are not only concerned on providing quality products or services but the key concern is to communicate with customers and understand their requirement to satisfy and retain them with a profitable relationship (Tseng, 2007). RM found ready acceptance in a marketing world where it had become obvious that strategic competitive advantage could no longer be delivered on the basis of product characteristics alone and where corporate profitability was beginning to become associated with satisfying existing customers (Egan, 2001). Kotler et al. (2007), defines relationship marketing as the process in which the construction, cultivation, and strengthening of strong value increase relationship with customers and other stakeholders.

Tourism and Hospitality industry has received rigorous attention of academics, business tycoons and economic analysts because of its growing effect on the GDP of a country (Uddin et al., 2008). In today's global economy, hospitality industry is one of the world largest and the most dynamic industry (Stancious etal., 2011). This industry is growing around the world and also become a major source of income generation and employment creation for several countries. The hospitality industry consist of large category of fields within the service industry that includes lodging, restaurants, event planning, theme parks, transportation, cruise line and additional fields within the tourisms industry(Olannye,2014). One category of hospitality industry is resort in which the researcher wants to conduct a comparative study on Haile and Lewi resorts. The study was conducted to assess the effect of customer relationship marketing on customer satisfaction in these resorts. The focus of this study was using relationship marketing dimensions that are trust, commitment, communication, empathy, and responsiveness and how these dimensions affects the satisfaction of customers in this resorts that does not get more concern by other researchers in this study area.

\subsection{Statement of the problem}

The challenge all marketers face today is to find ways in how to increase customer loyalty and retention. Today service providers are highly competitive, and this is very challenging for companies to provide unique services as required by customers, to overcome this challenge, companies can build effective interaction and relationship 
with their customers, because customer focus is on the service delivery system and interaction with the service provider when evaluating the service provider company. Managing customer relationship in business organizations is a challenging phenomenon, because customers' requirement can significantly vary and organizations are concentrated on different operations to meet their customer needs (Kleinaltenkamp and Ehret, 2006).

It is observed that, hospitality industry in Ethiopia in general and hotels and resorts in Hawassa particularly lack main concern about creating long lasting relationship with its customers and the effect of relationship marketing on their profitability and market share. Most of the hotels in Hawassa concern about the short term relationship with customers and they are profit oriented. Most hotel and resort managers have limited knowledge on relationship marketing dimensions and their effects on customer satisfaction. Because, most of the managers, employees and customers' have no adequate information about the relationship marketing dimensions and how they should be applied in particular hotels and resorts. Most of the employees of hotels and resorts are not well trained on how to create long term relationship with customers, that is why they are not effective in implementing relationship marketing dimension and creating long lasting relationship with the customers of hotels and resorts. Also there is no or limited research and journals in Ethiopia to support and inform managers, employees and customers about relationship marketing dimensions and their effects on customer satisfaction in case of hotels and resorts.

Although relationship marketing has been introduced as the forerunner of effective strategy to attract, sustain and enhance the relationships with customers, there exist few empirical studies which investigated the fundamental assumptions and were considered as the bases for the researches on relationship marketing (Ward and Dagger, 2007). Most of the studies have focused on the complexities of Customer Relationship marketing (Ward and Dagger, 2007), the barriers to Customer Relationship marketing (Pressey and Mathews, 2000) and Customer Relationship marketing as a process (Gronroos, 2004). There has been little emphasis on the relationship between customer relationship marketing and customer satisfaction.

In order to fill the research gaps that are stated above, the researcher interested to conduct a comparative study on assessing the effect of relationship marketing on customer satisfaction on Halie and Lewi resorts.

\subsection{Objectives of the Study}

\subsubsection{GENERAL OBJECTIVE}

The general objective of this study was to assess the effect of relationship marketing on Customers' satisfaction on the selected hotels in the southern Ethiopia Haile and Lewi resorts.

\subsubsection{SPECIFIC OBJECTIVES}

Based on the above general objective, the following specific objectives are drawn.

1. To examine the effect of trust on customers' satisfaction on Haile and Lewi resorts;

2. To explore whether commitment has an effect on customers' satisfaction on Haile and Lewi resorts;

3. To evaluate whether communication has an effect on customers' satisfaction on Haile and Lewi resorts;

4. To identify whether empathy has effect on customers' satisfaction on Haile and Lewi resorts; and

5. To investigate whether responsiveness has effect on customers' satisfaction on Haile and Lewiresorts;

6. To compare the results of both resorts in relation to relationship marketing dimensions and their effect on customer satisfaction.

\subsection{Research Hypothesis}

The study aimed to assess the effect of relationship marketing on customers' satisfaction in case of Haile and Lewi resorts. Based on the existing theoretical and empirical literature, this study explored the extent of customer satisfaction on resorts can be explained by relationship marketing variables such as trust, commitment, communication, empathy and responsiveness. Based on the research problems and objectives stated above, the following hypotheses were formulated.

$\mathrm{H}_{1}$ : Trust has no significant effect on customers' satisfaction.

$\mathrm{Ha}_{1}$ : Trust has significant effect on customers' satisfaction.

$\mathrm{HO}_{2}$ : Commitment has no significant effect on customers' satisfaction.

$\mathrm{Ha}_{2}$ : Commitment has significant effect on customers' satisfaction.

$\mathrm{HO}_{3}$ : Communication has no significant effect on customers' satisfaction.

$\mathrm{Ha}_{3}$ : Communication has significant effect on customers' satisfaction.

$\mathrm{HO}_{4}$ : Empathy has no significant effect on customers' satisfaction.

$\mathrm{Ha}_{4}$ : Empathy has significant effect on customers' satisfaction.

$\mathrm{H}_{5}$ : Responsiveness has no significant effect on customers' satisfaction.

$\mathrm{Ha}_{5}$ : Responsiveness has significant effect on customers' satisfaction. 


\section{REVIEW OF RELATED LITERATURE}

\subsection{Evolution of Relationship Marketing}

The main purposes of relationship marketing is creating and enhancing customer relationship starting from the beginning to satisfy and retain the existing customers, in the other way transactional marketing attempts to make the sale and acquire new customers rather than retaining the existing customers (Vence, 2002). According to Boulding et al., (2005), Dimitriadis and Stevens (2008), CRM is an integration of marketing activities and technological resources to create strong relationship firms with their customers. Customer relationship management focuses on building relationship, applying systematic way to collect and analyze data, and integrate all these activities throughout the firm, and enhancing the ability of integrating these activities throughout the network of firms that collaborate to generate customer value, while creating shareholder value for the firm.

\subsection{Theoretical Foundation of relationship Marketing 2.2.1RELATIONSHIP QUALITY THEORY}

Relationship quality captures multiple aspects or dimensions of a relationship (e.g., trust, commitment, relationship satisfaction) and has a stronger impact on objective performance than any single dimension. Thus, Palmatier et al., (2006), suggest that "different aspects or dimensions of a relationship may be synergistic, and performance is optimized only when the relationship is sufficiently strong on all critical aspects".

\subsubsection{THE COMMITMENT-TRUST THEORY}

Morgan and Hunt (1994), in "The Commitment-Trust Theory of Relationship Marketing" (perhaps the most influential RM paper to date), posit that "presence of relationship commitment and trust is central to successful relationship marketing, not power." They argued that trust and relationship commitment are the key mediators in exchange between participants, which essentially lead to building a relational co-cooperation. They insist that relationship commitment, "an enduring desire to maintain a valued relationship", and trust, the "confidence in an exchange partner's reliability and integrity" (Morgan and Hunt, 1994), and Morgan and Hunt, 1994

\subsubsection{Relationship Marketing in Service Industry}

The concept of relationship marketing emerged as an opponent to traditional marketing theories since early $1990 \mathrm{~s}$, when the paradigm shifted from transactional to relational marketing. At that time, marketers started to realize that a long lasting relationship is more profitable than a onetime transaction. This is in line with the fact that the cost of serving one loyal customer is five to six times less than the cost of attracting and serving one new customer (Ndubisi et al., 2009, Ndubisi, 2003, Reichheld et al., 2000). Since that, relationship marketing had received an increasing amount of attention in marketing research (Gronroos, 1994; 1999), especially in the service industry.

\subsubsection{Relationship Marketing Dimensions}

Chattananon and Trimetsoontorn (2009), in their study on relationship marketing in a business context used four common components including bonding, empathy, reciprocity and trust. It is different with the customer-based study of Ndubisi (2007), who employed trust, commitment, communication and conflict handling as key constructs of relationship marketing. As it is suggested by the researchers, there was no agreement on underpinning dimensions of relationship marketing for the study. But based on different academicians' avocation, the researcher was focus on the following dimensions of relationship marketing in order to determine the effect of relationship marketing on customer satisfaction.

\subsubsection{TRUST}

Trust is a variable considered as the basis of relational exchanges in the west. Trust is formed in the individual relationships. Individual characteristics including competence, honesty and reliability play crucial roles in creating trust. It leads to more implementable individual guaranties and affects the relationships, feedbacks and problem solving; finally, it creates more appropriate attitudes regarding mutual loyalty and long-term relationships (Leung et al., 2005). Trust will be created if one of the parts relies on the confidence and honesty of another part (Teo and Soutar, 2012, Rashid, 2003).

\subsubsection{COMMITMENT}

Other than trust, commitment is another important underpinning of relationship marketing and its definition is used differently across study settings. In psychology, scholars described commitment as a decision or recognition that fix or bind an individual to a behavioral disposition (Kiesler, 1971), while sociologist used the concept of commitment as a descriptive concept to mark out forms of action characteristics of particular kinds of people or groups (Wong and Sohal, 2002). Although various field of study defined commitment in slightly different ways, however marketing defined it as an enduring desire to maintain a value relationship (Moorman et al., 1992).

\subsubsection{COMMUNICATION}

Communication is defined as the understanding of consumers from the interaction of seller and buyer in a friendly and personal manner (Naoui and Zaiem, 2010) which is regarded as one of relationship marketing 
components serving as glue to sustain the cohesion of distribution channels (Hau and Ngo, 2012). It refers to the frequency and quality of information sharing between two parts and plays important roles in creating values and stronger relationships (Naoui and Zaiem, 2010). Making them aware is the responsibility of relationship creator. By enhancing the quality, value, performance and other features, customer priorities are met and probable customer is convinced and encouraged to make purchase decisions. Communications inform the customer about what the company is doing in order to compensate their dissatisfaction.

\subsubsection{EMPATHY}

Another component of relationship marketing is empathy resulting in taking the situation into consideration by one of the parts from the perspective of his/her partner. It is defined as the attempt to understand a person's tendencies and goals. Without empathy for understanding and accepting the buyer's needs, appropriate consequences are unlikely to be achieved. It facilitates the seller-buyer relationship and reinforces the buyer understanding of performance procedures in the industries (Hau and Ngo, 2012). In first stages, empathizing with the customer is important but as the relationship is developed, two parts' empathy will be of considerable importance. Being interested in another part develops individual and business relationships and presents a more positive perspective (Rashid, 2003). Chantal (2007), believed that a successful company is the one which knows its costumers completely and pays attention to their individual priorities, needs, expectations and problems.

\subsubsection{RESPONSIVENESS}

Responsiveness is a firm's ability to respond the needs and wants of its customers in timely manner. For a firm to be responsive, it must gain deeper understanding and profiling of customer behavior, real-time customer information and loyalty, management at Point of Service, optimized sales through cross-sell activities and rapid response to customers requirement. The firm's ability to respond the changing market conditions and increase customers choice, satisfaction and loyalty provides valuable to customers. Showing sincerity and willingness to help customers are some of the key issues in responsiveness and enhances customer retention (kuranchie, 2010).

\subsubsection{Customer satisfaction}

Relationship marketing theory suggests that profitability is enhanced when customer retention is high. Retention in competitive markets is generally believed to be a product of customer satisfaction (Buttle, 1997). In addition, customer satisfaction has been shown to be positively associated with return on investment (ROI) and market value (Sheth and Sisodia, 1999), although these are sometimes regarded as poor measures of actual company performance in the long term. Satisfaction can be perceived from a number of different viewpoints; however, most researchers agree that satisfaction is a psychological process of evaluating perceived performance outcomes based on predetermined expectations (e.g. Sheth and Sisodia, 1999). Customers are, therefore, satisfied when their 'expectations of values' are positively disconfirmed (Buttle, 1997).

Figure 2.1 Conceptual frame work of study Independent Variables

\section{Dependent Variable}

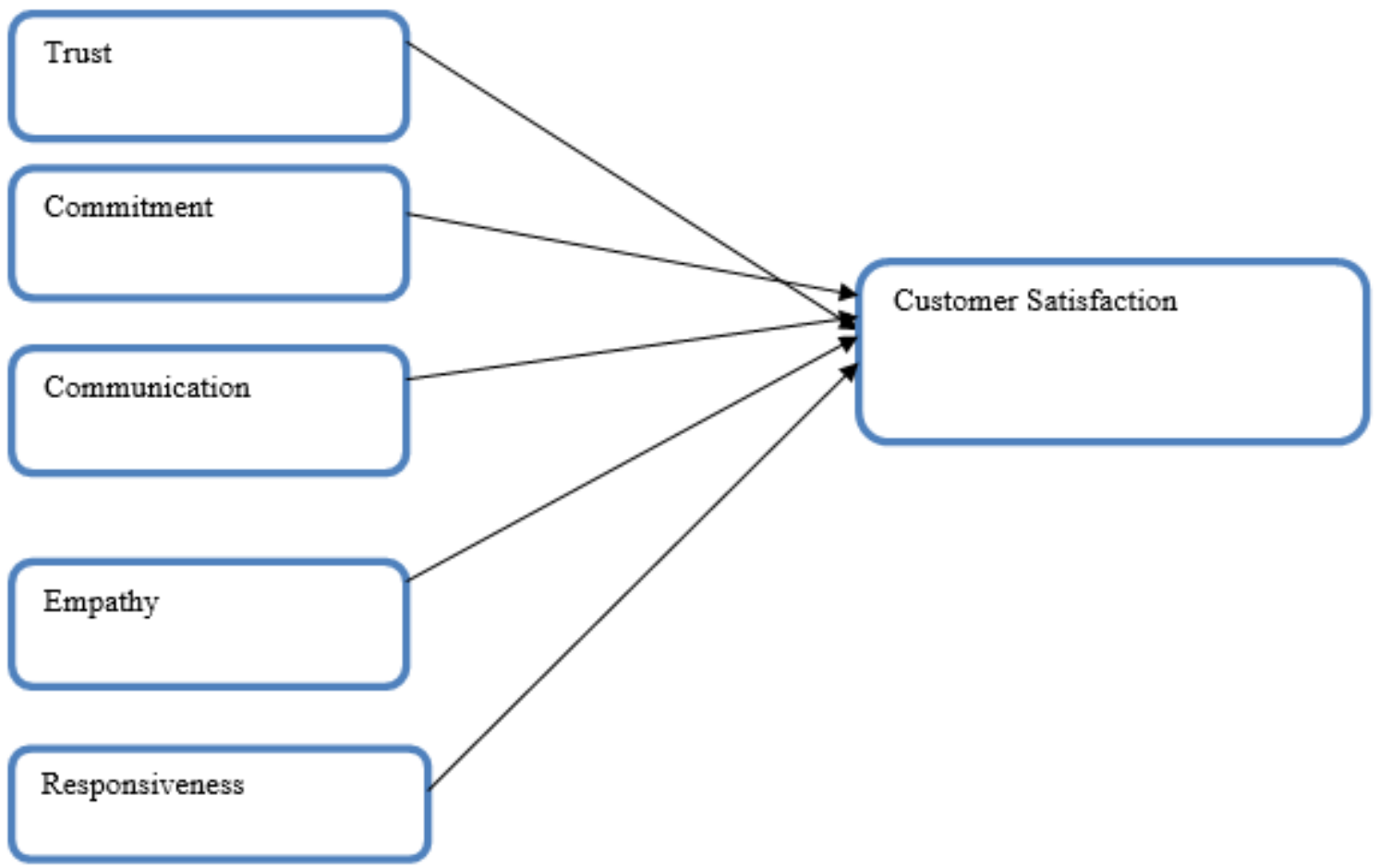

Source: Adopted from (Dambush Negasi, 2014) and modified by the researchers, 2018 


\section{Research Methodology \\ 3.1 Research Design}

The study implemented survey research with cross-sectional design. Because, cross-sectional survey research design is deemed appropriate for the study as it provides sufficient data to address the research problem within specified period of time. In this case, a Pilot study was conducted in this study. Convenience sampling method was used in order to collect data from customers' resorts. And also purposive sampling technique was used to select and collect further information's from managers each resort.

Data analyses were conducted by using descriptive and inferential analysis. The research was conducted on hawassa city by taking Haile and Lewi hotel and resorts customers and managers as target population in order to conduct comparative study.

\subsection{Target population Types and source of data}

The target population of this study was customers' of Haile and Lewi resorts. In addition managers of Haile and Lewi hotel and resorts were considered to get further information about the practices relationship marketing dimensions and their effect on customer satisfaction. The study was conducted based on primary and secondary data. The data were collected from relevant sources that help to achieve the above objectives of the study.

\subsection{SAMPLE Size Determination}

Since the total number of target populations of the resorts under the study were unknown, the researcher was employee the method determined by Cochran. The Cochran's formula for calculating sample size when the population is infinite: Cochran (1977) developed a formula to calculate a representative sample for proportions as:

$$
n_{0}=\frac{Z^{2} * \boldsymbol{p} *(1-p)}{e^{2}}
$$

Where, $\mathrm{n}_{0}$ is the sample size, $\mathrm{z}$ is the selected critical value of desired confidence level, $\mathrm{Z}^{2}$ is the abscissa of the normal curve that cuts off an area $\alpha$ at the tails ( $1-\alpha$ equals the desired confidence level is $95 \%$ ), The value for $\mathrm{Z}$ is found in statistical tables which contain the area under the normal curve.

$\mathrm{P}$ is the estimated proportion of an attribute that is present in the population,

$\mathrm{q}=1-\mathrm{p}$ and,

$\mathrm{e}$ is the desired level of precision.

The researcher wants to calculate a sample size of a large population whose degree of variability is not known. A proportion of 0.5 (or $50 \%$ ) indicates the greatest level of variability, more than either 0.2 or 0.8 . This is because 0.2 or 0.8 indicate that a large majority do not or do, respectively, have the attribute of interest. Because a proportion of 0.5 indicates the maximum variability in a population it is often used in determining a more conservative sample size, that is, the sample size may be larger than if the true variability of the population attribute were used. Assuming the maximum variability, which is equal to $50 \%(\mathrm{p}=0.5)$ and taking $95 \%$ confidence level with $\pm 5 \%$ precision, the calculation for required sample size was as follows:

$\mathrm{p}=0.5$ and hence $\mathrm{q}=1-0.5=0.5 ; \mathrm{e}=0.05 ; \mathrm{z}=1.96$ (From normal distribution table)

So, $\frac{\mathrm{n}_{0=(1.96)^{2}(0.5)(0.5)}=384.16}{(0.5)^{2}}=384$.

The total sample size of the study was 384 customers and purposefully 2 managers were selected from the Haile and Lewi hotel and resorts. After determining the sample size, the researcher distributed the total sample respondents equally to both resorts. That means,

\section{Model Specification}

The regression model was done in the form of:

$\mathrm{Y}=\beta 0+\beta 1 \mathrm{X} 1+\beta 2 \mathrm{X} 2+\ldots . .+\beta \mathrm{nXn}$

Where,

$\mathrm{Y}$ is dependent variable:-variable which is affected by other variables or explained by the independent variables Bo is constant

$\beta 1 \ldots \beta \mathrm{n}$ are the coefficient of the independent variables $\mathrm{X} 1$ to $\mathrm{Xn}$. Substituting both dependent and independent variables in equation above, we have the following equation

Specifically, for this study the expression is appropriate:

$\mathrm{CS}=\beta 0+\beta 1 \times 1+\beta 2 \times 2+\beta 3 \times 3+\beta 4 \times 4+\beta 5 \times 5$

Where,

$\beta 1$ is the partial slope for $\mathrm{x} 1$ on $\mathrm{y}$ and indicates the change in $\mathrm{y}$ for one unit change in $\mathrm{x} 1$, controlling $\mathrm{x} 2 \ldots \ldots \mathrm{x} 5$ is the same thing

CS - Customer satisfaction -dependent variable 
X1- Trust

$\mathrm{X} 2$ - commitment

$\mathrm{X} 3$ - communication

$\mathrm{X} 4$ - Empathy

X5- Responsiveness

\section{DATA PRESENTATION, ANALYSIS AND INTERPRETATION}

To collect the data and extract findings, questionnaire was prepared and distributed to customers of Haile and Lewi resorts in Hawassa city, thus a total of 384 questionnaire was distributed to two resorts in Hawassa city , and a total of $365(95 \%)$ was collected from two resorts and used for this study. This means that 185 questionnaire was collected from Haile resort and 180 questionnaire from Lewi resort. 19 (5\%) of the questionnaire remained uncollectible. On the whole, data collection lasted a total of four weeks.

\subsection{Respondents demographic characteristics}

This section presents about information of respondents such as gender, age, marital status, educational level, occupation and customers stay at Haile and Lewi resorts in Hawassa under the study.

Table 4.1 Demographic Backgrounds of Respondents

\begin{tabular}{|c|c|c|c|c|c|c|}
\hline \multirow[t]{3}{*}{ No } & \multirow[t]{3}{*}{ Indicators } & \multirow[t]{3}{*}{ Category } & \multicolumn{4}{|c|}{ Resorts } \\
\hline & & & \multicolumn{2}{|c|}{ Haile } & \multicolumn{2}{|c|}{ Lewi } \\
\hline & & & Frequency & Percent & Frequency & Percent \\
\hline \multirow[t]{2}{*}{1} & Sex & Male & 102 & 55.1 & 99 & 55 \\
\hline & & Female & 83 & 44.9 & 81 & 45 \\
\hline \multicolumn{3}{|c|}{ Total } & 185 & 100.0 & 180 & 100.0 \\
\hline \multirow[t]{5}{*}{2} & Age & $\leq 25$ & 59 & 31.9 & 45 & 25 \\
\hline & & $26-35$ & 68 & 36.8 & 77 & 42.8 \\
\hline & & $36-45$ & 38 & 20.5 & 32 & 17.8 \\
\hline & & $46-55$ & 20 & 10.8 & 17 & 9.4 \\
\hline & & 56 and Above & - & - & 9 & 5 \\
\hline \multicolumn{3}{|c|}{ Total } & 185 & 100.0 & 180 & 100.0 \\
\hline \multirow[t]{3}{*}{3} & Marital status & Married & 63 & 34.1 & 68 & 37.8 \\
\hline & & Single & 94 & 50.8 & 88 & 48.9 \\
\hline & & Other & 28 & 15.1 & 24 & 13.3 \\
\hline \multicolumn{2}{|c|}{ Total } & & 185 & 100.0 & 180 & 100.0 \\
\hline \multirow[t]{6}{*}{4} & Educational & Illiterate & 18 & 9.7 & 15 & 8.3 \\
\hline & level & Primary school & 27 & 14.6 & 19 & 10.6 \\
\hline & & Secondary school & 22 & 11.9 & 22 & 12.2 \\
\hline & & Diploma & 35 & 18.9 & 27 & 15 \\
\hline & & First degree & 55 & 29.7 & 72 & 40 \\
\hline & & Masters and above & 28 & 15.1 & 25 & 13.9 \\
\hline \multicolumn{3}{|c|}{ Total } & 185 & 100.0 & 180 & 100.0 \\
\hline
\end{tabular}

Source: (Own survey, 2018)

Table 4.1 above shows that majorities of respondents (55.1\%) were males and the rest $44.9 \%$ were females for Haile resort. And also 55\% of respondents were males and the rest $45 \%$ were females for Lewi resort. Comparing the percentages of males and females for both resorts, customers' population was male dominated.

As table indicated above for Lewi resort, $8.3 \%$ of respondents stay with the resort for less than one year. $22.8 \%$ of respondents were served for one year and $38.3 \%$ of respondents were stay with the resort for two years. The remaining $30.6 \%$ of respondents were used the services of resort for three and more than three years. This implies that majorities of respondents under the study used the services of the resorts for one year and above.

\subsection{Descriptive Analysis of the Study Variables}

This part of the analysis is made based on survey questionnaires gathered from 365 Customers of Haile and Lewi resorts using 5-point Likert's scale. The study has five independent variables such as trust, commitment, communication, empathy and responsiveness; it has customer satisfaction as a dependent variable.

The researcher considers, for his measure, an inherent assumption, which states that with the usage of any Likert scale that although the scale is truly ordinal in nature, it is assumed to be on an interval scale with which statistical properties such as the mean can be justifiably used. It is an assumption made quite frequently in empirical studies (Edmindson, 2005). Accordingly, the research applies mean and standard deviation as the best measures for analysis based on the mean range developed by Al-Sayaad et al. (2006, Cited in Demis, 2016) of 
the following table:

Table 4.2 Five- Scaled Likert's criterion

\begin{tabular}{|l|l|l|}
\hline No. & Mean Range & Response Options \\
\hline 1 & {$[1.00,1.80)$} & Strongly Disagree \\
\hline 2 & {$[1.80,2.60)$} & Disagree \\
\hline 3 & {$[2.60,3.40)$} & Neutral \\
\hline 4 & {$[3.40,4.20)$} & Agree \\
\hline 5 & {$[4.20,5.00]$} & Strongly Agree \\
\hline
\end{tabular}

Source: Al-Sayaad et al. (2006, Cited in Demis, 2016)

Table 4.3 Descriptive Statistics of items that measure trust

\begin{tabular}{|l|l|l|l|l|l|l|l|l|}
\hline \multirow{2}{*}{ Items } & \multicolumn{3}{l|}{ Haile Resort(N=185) } & \multicolumn{3}{l|}{ Lewi Resort(N=180) } \\
\cline { 2 - 9 } & Min. & Max. & Mean & $\begin{array}{l}\text { Std. } \\
\text { dev }\end{array}$ & Min. & Max. & Mean & $\begin{array}{l}\text { Std. } \\
\text { dev }\end{array}$ \\
\hline 1. I always trust the services of resort & 2 & 5 & 4.05 & 0.645 & 2 & 5 & 4.42 & 0.633 \\
\hline 2. The resort trusted on the service you ask & 2 & 5 & 4.09 & 0.702 & 2 & 5 & 4.41 & 0.632 \\
\hline $\begin{array}{l}\text { 3. The resort provides consistent quality } \\
\text { services at different time }\end{array}$ & 2 & 5 & 4.02 & 0.751 & 2 & 5 & 4.26 & 0.765 \\
\hline $\begin{array}{l}\text { 4. The resort always show respect and honest } \\
\text { to you }\end{array}$ & 1 & 5 & 4.26 & 0.750 & 1 & 5 & 4.46 & 0.582 \\
\hline $\begin{array}{l}\text { 5. The resort has the ability to meet its } \\
\text { promises }\end{array}$ & 2 & 5 & 4.03 & 0.726 & 1 & 5 & 4.28 & 0.635 \\
\hline Overall average for trust & 1.8 & 5 & 4.09 & 0.545 & 1.6 & 5 & 4.36 & 0.556 \\
\hline
\end{tabular}

Source: (Own survey, 2018)

The overall mean score of trust is 4.09 with the standard deviation of 0.545 for Haile resort and it has mean value of 4.3 with the standard deviation of 0.556 for Lewi resort. According to the criterion set under table 4.2, the mean value falls to "agree level" for Haile resort customers and "strongly agree level" for Lewi resort customers. This shows that Lewi resort is better in implementation of trust tactics as compared to Haile resort.

Table 4.4 Descriptive Statistics of items that measure commitment

\begin{tabular}{|c|c|c|c|c|c|c|c|c|}
\hline \multirow[t]{2}{*}{ Items } & \multicolumn{4}{|c|}{ Haile Resort( $\mathrm{N}=185)$} & \multicolumn{4}{|c|}{ Lewi Resort( $\mathrm{N}=180)$} \\
\hline & Min. & Max. & Mean & $\begin{array}{l}\text { Std. } \\
\text { dev }\end{array}$ & Min. & Max. & Mean & $\begin{array}{l}\text { Std. } \\
\text { dev }\end{array}$ \\
\hline $\begin{array}{l}\text { 1.The employees of resort always willing to } \\
\text { help you }\end{array}$ & 1 & 5 & 4.08 & 0.783 & 2 & 5 & 4.22 & 0.719 \\
\hline $\begin{array}{l}\text { 2.The resort changes its service to satisfy } \\
\text { your needs }\end{array}$ & 2 & 5 & 4.03 & 0.714 & 2 & 5 & 4.24 & 0.663 \\
\hline $\begin{array}{l}\text { 3.Employees are consistently polite during } \\
\text { service contact }\end{array}$ & 2 & 5 & 4.25 & 0.585 & 1 & 5 & 4.28 & 0.598 \\
\hline $\begin{array}{l}\text { 4.The resort strongly works to maintain } \\
\text { customer relationship }\end{array}$ & 2 & 5 & 4.21 & 0.602 & 1 & 5 & 4.23 & 0.615 \\
\hline $\begin{array}{l}\text { 5.The resort spends enough effort to keep } \\
\text { customer relationship }\end{array}$ & 3 & 5 & 4.16 & 0.619 & 1 & 5 & 4.23 & 0.667 \\
\hline Overall average for Commitment & 2 & 5 & 4.15 & 0.465 & 1.4 & 5 & 4.24 & 0.519 \\
\hline
\end{tabular}

Source: (Own survey, 2018)

The overall mean score of commitment is 4.15 with the standard deviation of 0.465 for Haile resort and it has mean value of 4.4 with the standard deviation of 0.519 for Lewi resort. According to the criterion set under table 4.4 above, the mean value falls to "agree level" for Haile resort customers and "strongly agree level" for Lewi resort customers. This implies that Lewi resort is good in performance of commitment elements than that of Haile resort.

Table 4.5 Pearson correlation result of Lewi resort Correlation is significant at the 0.01 level (2-tailed)

Based on table 4.6, Beta coefficient result responsiveness has maximum effect (0.332) and trust has minimum effect (0.106) on customer satisfaction. Regression model can be written as follows and significant at $95 \%$ confidence interval for Haile resort.

$\mathrm{Y}=0.393+0.106 \mathrm{x} 1+0.151 \times 2+0.209 \mathrm{x} 3+0.267 \mathrm{x} 4+0.332 \times 5$ 
Table 4.5 Multiple regression result of Lewi resort

\begin{tabular}{|c|c|c|c|c|c|}
\hline \multirow[t]{3}{*}{ Model 1} & \multicolumn{3}{|c|}{ Coefficients $^{\mathrm{a}}$} & \multirow[t]{3}{*}{$\mathrm{t}$} & \multirow[t]{3}{*}{ Sig. } \\
\hline & \multicolumn{2}{|c|}{$\begin{array}{l}\text { Unstandardized } \\
\text { Coefficients }\end{array}$} & Standardized Coefficients & & \\
\hline & $\mathrm{B}$ & Std. Error & Beta & & \\
\hline (constant) & .531 & .200 & & 2.656 & .009 \\
\hline $\mathrm{X} 1=$ Trust & .180 & .056 & .208 & 3.226 & .001 \\
\hline $\mathrm{X} 2=$ Commitment & .039 & .060 & .042 & .652 & .515 \\
\hline X3=Communication & .185 & .063 & .193 & 2.952 & .004 \\
\hline $\mathrm{X} 4=$ Empathy & .210 & .052 & .252 & 4.020 & .000 \\
\hline X5=Responsiveness & .253 & .057 & .289 & 4.485 & .000 \\
\hline
\end{tabular}

Source: (Own survey, 2017)

Dependent Variable: Customer satisfaction

According to table 4.19, Beta coefficient value responsiveness has maximum effect $(0.289)$ and commitment has minimum effect (0.042) on customer satisfaction. Regression model can be written as follows and significant at $95 \%$ confidence interval for Lewi resort.

$\mathrm{Y}=0.531+0.208 \times 1+0.042 \times 2+0.193 \times 3+0.252 \times 4+0.289 \times 5$

As it was indicated above, Trust has positive effect on customer satisfaction. This means that, as trust increases or decreases by $1 \%$, customer satisfaction increases or decreases by $20.8 \%$ controlling (x2, x3, x4 and $\mathrm{x} 5$ ). And also Commitment influences customer satisfaction positively. When commitment is raised or fall by $1 \%$, the customer satisfaction raised or fall by $4.2 \%$ controlling ( $1, x 3, x 4$ and $\times 5)$. As Communication increased or decreased by $1 \%$ customer satisfaction also increased or decreased by $19.3 \%$ keeping other variables constant $(\mathrm{x} 1, \mathrm{x} 2, \mathrm{x} 4$ and $\mathrm{x} 5)$.with regard to empathy increased or decreased by $1 \%$, customer satisfaction is increased or decreased by $25.2 \%$ keeping other variables remain the same $(\mathrm{x} 1, \mathrm{x} 2, \mathrm{x} 3$ and $\mathrm{x} 5)$.

Finally, responsiveness increased or decreased by $1 \%$, customer satisfaction is increased or decreased by $28.9 \%$ keeping other variables constant $(\mathrm{x} 1, \mathrm{x} 2, \mathrm{x} 3$ and $\mathrm{x} 4)$. This implies that responsiveness and empathy have strong impact on customer satisfaction in case of Lewi resort.

\section{SUMMARY OF FINDINGS, CONCLUSIONS AND RECOMMENDATIONS \\ 5.1 Findings and Conclusions}

The analysis results of the research shows that from all independent variables of relationship marketing under the study, commitment, communication, empathy and responsiveness have strong correlation with customer satisfaction for Haile resort. But trust has moderate correlation with customer satisfaction. It was highly significant at the 0.01 level $(\mathrm{p}<0.01)$. Trust, communication, empathy and responsiveness have strong correlation with customer satisfaction for Lewi resort. However, commitment has moderate correlation with customer satisfaction. It was significant at the 0.01 level $(\mathrm{p}<0.01)$ This finding implies that, both Haile and lewi resorts has to provide more concern on tactics of relationship marketing that can highly affect customer satisfaction and their performance in the market.

The regression analysis showed that $\mathrm{R}$ Square $=.711$ means all independent variables (trust, commitment, communication, empathy and responsiveness) can explain customers satisfaction by 71.1 percent in case of Haile resort. And also for Lewi resort, R Square $=.680$ means all independent variables (trust, commitment, communication, empathy and responsiveness) can predict customer satisfaction by 68.0 percent. Generally, the findings of the analysis made above revealed that there is strong and significant relationship among independent and dependent variables.

Furthermore, interview analysis results show that implementing customer relationship strategies in the resorts have paramount importance in acquiring and satisfying both actual and potential customers and to generate profit in the relationship.

\subsection{Recommendations}

From the findings of this thesis, the researcher has point out some problems on variables under the study. To fill the gaps of problems and to let the resorts to sustain strengthens, the following recommendations were made:

$>$ The resorts would provide consistent quality services at different time by adjusting overall service structure and working environment in similar manner and by allocating employees with competency in the profession. And also the resorts should work hard to develop their capacity to meet promises by shaping its work plan, adopting new changes in business environment and effectively determining the demand of customers in the market and adjusting supply of services accordingly.

$>$ Resorts should inspire their employees by involving many fringe benefits other than their normal salary in order to persuade them to show interest during service contact with the customers. And in addition 
providing training and awareness for employees about the effect relationship with customers on achieving organizational objectives.

$>$ Here the resort had better provide the chances to its customers to express their feeling about any service related issues. And giving freedom to the customers to provide the opinions about the services of the resort is the issue that needs concern from the resort.

$>$ The employees of the resort understand customers' specific needs have relatively low mean value for Lewi resort. So, resort should inform, and train its employees with how to understand the specific needs of many customers with different conditions of service.

$>$ The resort services/products accessibility are improved to satisfy customer need from customer satisfaction items, has relatively low mean value for two resorts. Based on the result, the resorts have a duty to improve their products convenience to satisfy the needs by employing different service delivery techniques.

\section{References}

Aali, S., Ibrahimi, A., Mirabi, V.R., Zare, R. 2014, 'Effects of Relationship Marketing Strategies on Customer Responses in Iran's Banking Industry: Role of Mediator the Relationship Quality', Research Journal of Recent Sciences, Vol. 3(5), pp. 43-54.

Aaltonen, P. 2004, Customer relationship Marketing and effect of Demographic and technology on customer satisfaction and loyalty in financial services, $\mathrm{PhD}$ unpublished thesis, Old Dominion University.

Abbasi, M.R. and Turkamani, M. 2010, 'Theoretical Models of Customer Relationship Management', Journal of Commerce Reviews, No. 41, pp. 34-39.

Adam, A. S., Stalcup, L. D., and Lee, A. 2010, 'Customer Relationship Management for Hotels in Hong Kong', International Journal of Contemporary Hospitality Management, Vol. 22(2), pp.139-159.

Al-Sayaad, J., Rabea, A., and Samrah, A., 2006, Statistics for Economics and Administration Studies. Dar Hafez, Jeddah, Kingdom of Saudi Arabia. In Abera,D. 2016, Assessment of Consumers' Buying Behavior towards Nonlife Insurance Products of Africa Insurance Company (S.C.), Hawassa Branch, MBA thesis, Hawassa University.

Asmamaw, A. 2016, The Effect Of Customer Relationship Marketing On Customer Retention: A Case Study Of Commercial Bank Of Ethiopia, MBA Thesis, St.Mary's University.

Barlow J. and Maul, D. 2000, Emotional Value: Creating strong bonds with your customers, Berret Kohler Publishers, San Francisco.

Barnes, J. 2002, 'The impact of technology on customer relationships', Australian Marketing Journal, Vol. 9(1), pp.21-31.

Barry, J.M., Dion, P. and Johnson, W. 2008, 'A Cross-cultural Examination of Relationship Strength in B2B Services', Journal of Services Marketing, Vol. 22(2), pp.114-135.

Bhardwaj, Deepali. 2007, 'Relationship Marketing in Context to the IT Industry', VISION-The Journal of Business Perspective, Vol.11, (2), pp. 57- 66.

Bhattacherjee, A., 2012, Social Science Research: Principles, Methods, and Practices.

University of South Florida: Scholar Commons. In Demis,A. 2016, Assessment of Consumers' Buying Behavior towards Nonlife Insurance Products of Africa Insurance Company (S.C.), Hawassa Branch, MBA thesis, Hawassa University.

Bitner, M.J., Booms, B.H. and Tetreault, M.S. 1994, 'The service encounter: Diagnosing favorable and unfavorable incidents', Journal of Marketing, Vol.54, pp. 71-84.

Boulding, W., Staelin, R., Ehret, M., Johnston, W. J. 2005, 'A customer relationship management roadmap: what is known, potential pitfalls, and where to go', Journal of Marketing, Vol. 69(4), pp.155-66.

Bowen, J. T. and Shoemaker, S. 2003, 'Loyalty: A Strategic Commitment, Cornell Hotel and Restaurant Administration Quarterly', Vol. 44, 5/6, pp.31-46.

Bryman, A. and Bell, E. 2003, Business Research Methods, New York: Oxford University Press Inc.

Bruhn, M. 2003, Relationship marketing: management of customer relationships, London: Prentice Hall.

Buttle, F.B. 1997, 'Exploring relationship quality', paper presented at the Academy of Marketing Conference, Manchester, UK

Chantal Ammi, 2007, 'Global Consumer Behavior', ISTE Ltd.

Chattananon, A. and Trimetsoontorn, J. 2009, 'Relationship marketing: a Thai case', International Journal of Emerging Markets, Vol. 4(3), pp. 252-274.

Coote, L.V., Forrest, E.J. and Tam, T.W. 2003, 'An Investigation into Commitment in Non-Western Industrial Marketing Relationships',Industrial Marketing Management, Vol.32(7), pp.595-604.

Crosby, L.A., Evans, K.R. and Cowles, D. 1990, 'Relationship quality in services selling: an interpersonal influence perspective', Journal of Marketing, Vol. 54 (3), pp.68-81.

Cummings, T. 1984, 'Transorganizational development', Research in Organizational Behavior, Vol. 6, pp.367- 
422.

Cyr, D., Hassanein, K., Head, M. and Ivanov, A. 2007, 'The Role of Social Presence in Establishing Loyalty in E-service Environments', Interacting With Computers, Vol.19 (1), pp.43-56.

Dambush N. 2014, The Role of Customer Relationship Marketing on Customer Retention: A case of Ethiopian Insurance Corporation, MBA Thesis, Mekelle University.

Ebisa Gobena and Andualem Gudeta 2013, 'Hotel Sector Investment in Ethiopia', Journal of Economics and international business research, Addis Ababa.

Edmindson, R. 2005, Likert Scales: A History. University of South Florida: USA.

Kotler, P., 2002, Marketing management: analysis, planning, implementation and control, Prentice Hall, Englewood Cliff, NJ.

Kucukkancabas, S., Akyol, A. and Ataman, B.M. 2009, Examination of the effects of the relationship marketing orientation on the company performance, Research Note, 43, 441-450. DOI 10.1007/s11135-007-9119-x.

Teo, Raymond, Geoffrey N. Soutar, 2012, 'Word of mouth antecedents in an educational context: a Singaporean study', International Journal of Educational Management, Vol. 26, No. 7, pp. 678-695.

Theron, E. and Terblanche, N. S. 2010, 'Dimensions of Relationship Marketing in Businessto-business Financial Services', International Journal of Market Research, Vol. 52(3), pp.383-402.

Yau, O.H.M., Sin, L.Y.M., Lee, J.S.Y. and Tse, A.C.B. 1998, The development of a scale for measuring relationship marketing orientation, Working Paper RCCM99-01-0, Chinese Management Research Centre, City University of Hong Kong.

Zeithaml, V.A., Berry, L.L and Parasuraman, A. 1993, 'The Nature and Determinant of Customer Expectation of Service', Academy of Marketing Science, Vol. 21(1), pp.1-12. 